\title{
PHYSICAL ACTIVITY AND LIFESTYLE OF OLDER ADULTS IN THE CONTEXT OF DISEASES OF AFFLUENCE
}

\author{
Alena Buková ${ }^{1}$, Agata Horbacz ${ }^{1}$, Ladislav Kručanica ${ }^{1}$, Mária Majherová ${ }^{2}$ \\ ${ }^{1}$ Pavol Jozef Šafárik University in Košice, Institute of Physical Education and Sport, Slovak Republic \\ ${ }^{2}$ University od Prešov, Faculty of Humanities and Natural Sciences, Slovak Republic, alena.bukova@upjs.sk
}

https://doi.org/10.29038/2220-7481-2019-02-61-65

\begin{abstract}
Introduction. In this study, we focused on physical activity of older adults and their lifestyle in the context of diseases of affluence. We monitored the most common physical activity performed by older adults, weekly frequency of the chosen physical activity, together with the prevalence of diseases of affluence and the assessment of the life quality of older adults. Methods. The study group comprised active older adults $(\mathrm{n}=35)$ who performed regular physical activity two and more times weekly, with two times a week under the supervision of an experienced instructor, and inactive older adults $(\mathrm{n}=35)$ whose physical activities consisted of only short walks and irregular exercise. Results. We found a lower prevalence of diseases of affluence among active older adults compared to the inactive. The differences are significant, especially in peripheral vascular disorders, osteoporosis, and diabetes. However, a statistically significant difference was only found in problems with blood pressure. Half of the inactive older adults reported that the diseases had restricted their physical activity, but they did not feel the need for any additional physical exercise. As we assumed, a significantly higher number of active older adults was recorded in the group with higher life quality. Conclusion. We agree with opinions of professionals in the field who recommend PA to be a natural and everyday part of a daily routine not only in younger age groups but also in retirement. There is a higher prevalence of chronic diseases in older adults, and therefore, they should understand the importance and meaning of PA in alleviating the irreversible process of aging.
\end{abstract}

Key words: older adults, physical activity, diseases of affluence, lifestyle.

Алена Букова, Агата Горбач, Ладіслав Кручаніца, Марія Махерова. Фізична активність і спосіб життя людей похилого віку, які страждають на хвороби достатку. Актуальність. У цьому дослідженні ми сфокусували свою увагу на фізичній активності та способі життя людей похилого віку, які страждають хворобами достатку. Ми виявили найпоширенішу фізичну активність, яку виконують люди похилого віку, щотижневу частоту обраної фізичної активності, а також поширеність захворювань достатку та оцінку якості життя людей похилого віку. Мeтоди. До дослідницької групи увійшли фізично активні люди похилого віку $(\mathrm{n}=35)$, які займалися спортом двічі й більше разів на тиждень, двічі на тиждень під наглядом досвідченого інструктора, та фізично неактивні люди похилого віку $(\mathrm{n}=35)$, фізичні навантаження яких складалися з коротких прогулянок і нерегулярних вправ. Результати дослідження. Ми виявили нижчу поширеність захворювань достатку серед активних людей похилого віку, порівняно з фізично неактивними. Відмінності є значними, особливо при серцево-судинних розладах та хворобах периферійних артерій, остеопорозі й діабеті. Однак статистично значуща різниця простежується лише в проблемах з артеріальним тиском. Половина фізично неактивних людей похилого віку сказали, що захворювання обмежували їхню фізичну активність, але вони не відчували необхідності в додаткових фізичних навантаженнях. Як ми й думали, у групі з вищою якістю життя зафіксовано значно більшу кількість фізично активних людей похилого віку. Висновки. Ми погоджуємося 3 думкою професіоналів у цій галузі, які рекомендують ФА як природну та невід'ємну частину повсякденного життя не тільки молодших вікових груп, але й людей похилого віку. Особи похилого віку в більшій групі ризику появи хронічних захворювань, а тому вони повинні розуміти важливість і значення ФА в полегшенні незворотного процесу старіння.

Ключові слова: люди похилого віку, фізична активність, хвороби достатку, спосіб життя.

Алена Букова, Агата Горбач, Ладислав Кручаница, Мария Махерова. Физическая активность и образ жизни пожилых людей, страдающих заболеваниями достатка. Актуальность. В этом исследовании мы сфокусировали свое внимание на физической активности и образе жизни пожилых людей, страдающих болезнями изобилия. Мы обнаружили самую распространенную физическую активность, которую выполняют люди пожилого возраста, еженедельную частоту выбранной физической активности, а также распространенность заболеваний достатка и оценку качества жизни пожилых людей. Методы. К исследовательской группе вошли физически активные люди пожилого возраста ( $\mathrm{n}=35)$, которые занимались спортом дважды и больше раз в неделю, два раза в неделю под наблюдением опытного инструктора, и физически неактивные люди пожилого возраста ( $\mathrm{n}=35)$, физические нагрузки которых состояли из коротких прогулок и нерегулярных упражнений. Peзультаты исследования. Мы обнаружили низкую распространенность заболеваний достатка среди активных пожилых людей, 
по сравнению с физически неактивными. Различия являются значительными, особенно при сердечно-сосудистых расстройствах и болезнях периферических артерий, остеопорозе и диабете. Однако статистически значимая разница прослеживается в проблемах с артериальным давлением. Половина физически неактивных людей пожилого возраста сказали, что заболевания ограничивали их физическую активность, но они не испытывали необходимости в дополнительных физических нагрузках. Как мы и думали, в группе с высоким качеством жизни было зафиксировано значительно большее количество физически активных пожилых людей. Выводы. Мы согласны с мнением профессионалов в этой области, которые рекомендуют ФА как естественную и неотъемлемую часть повседневной жизни не только младших возрастных групп, но и пожилых людей. Пожилые люди в большей группе риска появления хронических заболеваний, поэтому они должны понимать важность и значение ФА в облегчении необратимого процесса старения.

Ключевые слова: старики, физическая активность, болезни достатка, образ жизни.

Introduction. Aging is a continuous and progressive process gradually leading to a decline in physiological functions in all organ systems [7]. This results in increased vulnerability to infections and diseases which dramatically increase the risk of mortality at this age. In fact, compared to 25-44 years of age, mortality risk among older adults is elevated by 100 -fold for stroke and chronic lung disease, roughly 90 -fold for heart disease, pneumonia and influenza, and over 40-fold for cancer [13].

Health promotion strategies for older adults generally have three fundamental objectives: maintaining and enhancing functional capacity, maintaining and improving self-care, and social network stimulation. The idea behind these strategies is to make life longer, more independent, and self-supporting (WHO, 2015). Prevention is the most effective way in averting unwanted diseases in older adults. One of the primary ways of prevention is regular physical activity (PA), which can bring considerable health benefits to people across the life-span. The need for regular physical activity does not end in older age; on the contrary, performing PA systematically can prolong years of active, independent life, decrease the effects of health disabilities and improve life quality of older people [6]. In our study, we focused on the physical activity of older adults and their lifestyle in the context of diseases of affluence. We monitored what physical activity older adults prefer, weekly frequency of the chosen physical activity as well as the prevalence of diseases of affluence and assessment of older adults' life quality.

Material and Methods. The study comprised active older adults (hereafter organised group - OG; $n=35$ ) who perform physical activity at least twice a week, with two times a week under the supervision of an experienced instructor; and inactive older adults (hereafter non-organised group - NG; $n=35$ ) whose physical activity included mainly short walks and irregular exercise. The average age of older adults at the time of research was 72,03 $\pm 5,9$ years. Basic demographic indicators are presented in table 1 .

Table 1

Basic Demographic Indicators of Older Adults Involved in the Survey (n=70)

\begin{tabular}{|l|ccl|c|c|c|c|}
\hline Study Group & \multicolumn{2}{|l|}{ Total Female Male } & $\begin{array}{c}\text { Age } \\
\text { Average }\end{array}$ & $\begin{array}{c}\text { Age } \\
\text { min }\end{array}$ & $\begin{array}{c}\text { Age } \\
\text { max }\end{array}$ & $\begin{array}{c}\text { Age } \\
\text { SD }\end{array}$ \\
\hline $\begin{array}{l}\text { Organised group } \\
\text { (OG) }\end{array}$ & 35 & 35 & 0 & 71.83 & 62 & 87 & 6,07 \\
\hline $\begin{array}{l}\text { Non-organised } \\
\text { group (NG) }\end{array}$ & 35 & 17 & 8 & 72.34 & 62 & 85 & 5,86 \\
\hline
\end{tabular}

Our main focus was the concept of physical activity related to the quality of life and to non-infectious diseases of affluence. A questionnaire created by Jones \& Rose (2005) was used as an instrument to collect the above-mentioned data, of which, for the purposes of this study we selected only specific related questions. Pearson's chi-square was used for data processing and evaluation. Statistical significance was assessed at $\mathrm{p}<0,05$ and $\mathrm{p}<0,01$. Processing and evaluation of the collected data were carried out using the statistic program Statistica v.12 and Excel 2010.

Results. Physical activity plays an important role in the life of older adults. Unfortunately, many older adults do not consider physical activity crucial for their health. As seen in table 2, almost $43 \%$ of older adults from the non-organised group do not perform any weekly PA. Nevertheless, it is highly positive that we found individuals practising some form of activity on an everyday basis including walks, which was the most popular PA among older adults in the non-organised group (table 3). The second most common activities in this group were home exercising and gardening. Older adults from the OG group perform PA mostly twice a week (60\%) and $17 \%$ of them perform PA three times a week. The most common PAs performed by older adults besides organized exercise and walks are swimming, cycling, and exercising at home. The results even imply that older adults from 
the OG group feel a greater need to be active than the NG group (46\% vs. $9 \%$; table 4). This relation was confirmed statistically as well $(\chi 2=12,2085, \mathrm{p}<0,01$; table 2$)$. We also found that older adults in the NG group subjectively feel more limited by their diseases in performing PA compared to the OG group $(\chi 2=6,34, p<0,05$; table 4).

Table 2

Older Adults' Weekly Frequency of PA

\begin{tabular}{|l|c|c|c|c|c|c|c|c|}
\hline \multicolumn{10}{|c|}{ Weekly Frequency of PA (\%) } \\
\hline Frequency of PA & $\mathbf{0 x}$ & $\mathbf{1 x}$ & $\mathbf{2 x}$ & $\mathbf{3 x}$ & $\mathbf{4 x}$ & $\mathbf{5 x}$ & $\mathbf{6 x}$ & $\mathbf{7 x}$ \\
\hline OG $(\mathrm{n}=35)$ & 0 & 0 & $\mathbf{6 0}$ & $\mathbf{1 7 , 1}$ & 11,4 & 2,9 & 2,9 & 5,7 \\
\hline NG $(\mathrm{n}=35)$ & $\mathbf{4 2 , 9}$ & 14.3 & $\mathbf{1 7 , 1}$ & 11,4 & 0 & 2,9 & 0 & 11,4 \\
\hline
\end{tabular}

Type of PA

Table 3

\begin{tabular}{|c|c|c|c|c|c|c|c|c|c|c|c|c|c|}
\hline PA & 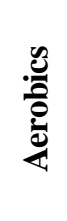 & 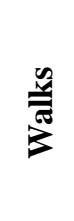 & 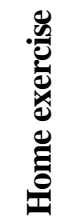 & 最 & 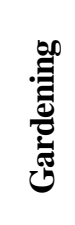 & 弱 & 些 & 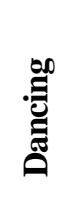 & 量 & $\underset{\nabla}{\mathbb{0}}$ & 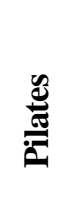 & D. & $\begin{array}{l}\overleftrightarrow{\mathrm{a}} \\
\dot{0}\end{array}$ \\
\hline OG & 100 & 94,3 & 14,3 & 22,9 & 2,9 & 14,3 & 11,4 & 5,7 & 8,6 & 8,6 & 5,7 & 0 & 0 \\
\hline NG & 0 & 62,9 & 31,4 & 2,9 & 11,4 & 2,9 & 5,7 & 5,7 & 5,7 & 0 & 0 & 5,7 & 22,9 \\
\hline
\end{tabular}

Need for Additional PA and Exercise Limitations

Table 4

\begin{tabular}{|c|c|c|c|}
\hline \multicolumn{4}{|c|}{ Need for Additional PA } \\
\hline Need for add & Yes $(\%)$ & No & \multirow{3}{*}{$\mathrm{p}=0,000476$} \\
\hline OG $(n=35)$ & 45,7 & 54,3 & \\
\hline NG $(n=35)$ & 8,6 & 91,4 & \\
\hline \multicolumn{4}{|c|}{ Diseases and Exercise Limitations } \\
\hline Limitations & yes $(\%)$ & & \multirow{3}{*}{$\mathrm{p}=0,0118$} \\
\hline OG $(n=35)$ & 20 & 80 & \\
\hline NG $\quad(n=35)$ & 51,4 & 48,6 & \\
\hline
\end{tabular}

Older adults in both groups mostly admitted a moderately high quality of life (table 5). In this respect, more active older adults were found in the group with higher quality of life. On the other hand, none of the older adults from the OG group reported low or poor quality of life. In the NG group, up to $20 \%$ of older adults indicated low quality of life. After merging the categories of high and very high quality of life and merging the middle and low quality of life categories, we found a positive correlation between the groups in favour of the active older adults $\left(\chi^{2}=5.18518, \mathrm{p}<0,05 ;\right.$ table 5$)$.

Table 5

Perceived Quality of Life of Older Adults

\begin{tabular}{|l|c|c|c|c|c|}
\hline \multicolumn{7}{|c|}{ Perceived Life Quality of Older Adults p=0,02278 } \\
\hline Quality of life & Very high & High & Moderate & Low & Very low \\
\hline OG $(\mathrm{n}=35)$ & 5,9 & $\mathbf{3 1 , 7}$ & 62,4 & 0 & 0 \\
\hline NG $(\mathrm{n}=35)$ & 2,8 & 14,3 & 62,4 & $\mathbf{2 0 . 5}$ & 0 \\
\hline
\end{tabular}

The number of health issues in older adults is steadily increasing. Many problems are caused by inappropriate lifestyle while others are a natural part of aging. The fact that only four older adults from the OG group admitted more than one chronic disease was a positive finding (tab. 4). Contrary to that, most older adults 
from the NG group suffered from two or more diseases; Moreover, only one third of them reported only one disease. The most common illness observed in both groups was high blood pressure and osteoporosis. Except for high blood pressure, where we found minimal differences between the active and inactive group, we found more significant differences in the other conditions to the detriment of the NG group. In neither case though, the regularity of PA correlates with the prevalence of diseases.

However, we found significant connections regarding high blood pressure - the most prevalent disease in both groups. We found that if the OG group older adults had additional workouts on top of their standard two exercise units weekly, they did not indicate blood pressure problems. On the contrary, older adults from the NG group who do not exercise at all were more likely to have blood pressure problems than those who performed any PA whatsoever $(\chi 2=4.375, \mathrm{p}<0,05)$. Also, older adults who reported higher quality of life were less likely to have blood pressure problems compared to those who reported medium quality of life $\left(\chi^{2}=6.02151, p<0,05\right)$.

Medical Conditions of Older Adults

Table 6

\begin{tabular}{|l|c|c|c|}
\hline Disease & OG $(\mathbf{n = 3 5}) \boldsymbol{~} \%$ & NG $(\mathbf{n = 3 5}) \boldsymbol{~} \%$ & Significance \\
\hline Peripheral vascular disease & 8,6 & 17,1 & 0,284 \\
\hline High blood pressure & 54,3 & 57,1 & 0,809 \\
\hline Diabetes & 2,9 & 14,3 & 0,087 \\
\hline Respiratory diseases & 2,9 & 5,7 & 0,555 \\
\hline Osteoporosis & 14,3 & 22,9 & 0,356 \\
\hline Cancer & 8,6 & 17,1 & 0,284 \\
\hline Rheumatoid arthritis & 5,7 & 2,9 & 0,555 \\
\hline Other arthritic diseases & 14,3 & 8,6 & 0,452 \\
\hline
\end{tabular}

Discussion. Dramatic global aging of the population has placed new demands on improving the health of older adults by adding «quality» to their prolonged lives [3]. Taking into account dramatically disproportional use of healthcare resources by older adults, maintaining their health and well-being is of the utmost importance for both scientific and general healthcare. Despite WHO and other PA supporting organizations' recommendations, physical inactivity is becoming a global healthcare burden [10]. Carefully supervised PA appears to be a priority of the global public health for developing effective non-communicable disease programmes [8]. In our research we found a significant percentage of older adults who do not exercise at all. Such finding is even more worrying when taking into account that the forms of physical activity considered in the research included very simple ones such as going for a walk, the most common physical activity of the inactive older adults. Yet there are numerous studies declaring advantages of regular PA, especially in old age and many of those provide sufficient scientific evidence. For illustration, in the 13 years of monitoring middle-aged and older-aged males, found that the physically active lifestyle was connected with life expectancy prolonged by 2,5 years. Another extensive 8-year study found that every additional 15 minutes of daily PA up to 100 minutes a day resulted in a $4 \%$ decrease in mortality, independent of its reason. On the other hand, as according to Buford (2017), reducing such essential functions as walking is already a strong predictor of future cardiovascular events $[2 ; 4 ; 14]$.

The health condition of older adults poses an exceptionally complex problem (Fried et al., 1998). They increasingly suffer from accumulated health issues. In our study, we found fewer health issues in physically active older adults. Those who did not perform regular PA reported a higher number of subjective health problems; the difference compared to physically active older adults was not significant though. The question arises, whether inactive older adults do not perform PA because of their accumulated health problems or the opposite, they suffer from health problems as a result of their inactivity. Poor health condition and chronic pain limits the performance of PA and can easily demotivate older adults. Diseases may reduce or even cause loss of the ability to move. Up to $50 \%$ of inactive older adults in our study pointed at this barrier as a limitation to perform PA. On the contrary, only as many as $20 \%$ of the active older adults stated that health problems limited their PA; Despite that, they performed PA regularly, at least twice a week. Evidence suggests that poor physical health is the most common barrier preventing physical activity by older adults. Thus, chronic health problems can substantially correlate with PA by older adults [11].

Based on our findings, as well as the results of other studies, we can confirm that regular PA has a positive association with perceived life quality. Such result corresponds with the study by Albuquerque et al. (2017), who 
monitored the influence of PA on life quality and cognitive processes in active and inactive older adults. These results confirm that satisfying life quality is closely associated with a healthy lifestyle, inherently including PA [1; $5 ; 9 ; 12]$.

Conclussion. Maintaining appropriate physical condition in old age is an inevitable part of healthy aging. Improving physical and mental health by means of physical activity is easy and financially not demanding. The results of our research correspond with many other studies that highlight benefits of PA in senior age. Based on these results, we cannot claim explicitly that PA reduces specific health problems mostly caused by aging or inappropriate lifestyle; however, we can say that PA is an essential part of a healthy lifestyle, which is closely related to the perceived quality of life at this age. Based on the above findings, we conclude that older adults should be provided more opportunities to perform organized PA meeting their needs and interests. Eventually, such approach would not only impact their quality of life, but also improve the use of healthcare resources particularly aimed at older adults.

Funding. This study was supported by the scientific Grant Agency of the Ministry of Education, Science, Research and Sport of the Slovak Republic and the Slovak Academy of Sciences under the Grant No. 1/0825/17 «Recommendations for physical activities in prevention and control of non-communicable diseases and their implementation in the eastern part of Slovakia».

Ethics Approval and Consent to Participate. The protocol was approved by the Human Research Ethics Committee of Pavol Jozef Šafárik University in Košice (approval No. PJSU-0825/17-1).

Competing Interests. The authors declare that they have no competing interests.

\section{References}

1. Albuquerque, A.P.A., Borges-Silva, F., Borges, G.S. et al. (2016). Physical Activity: Relationship To Quality Of Life And Memory In Older People. Science and Sport, 32(5), 259-265. doi.org/10.1016/ j.scispo.2016.09.006.

2. Bellavia, A., Bottai M, Wolk, A.,Orsini, N. (2013) Physical activity and mortality in a prospective cohort of middleaged and elderly men - a time perspective. International J. of Behav. Nutrit. and Phys. Activity, 10, 94. doi.org/10.1186/1479-5868-10-94.

3. Bowling, A. (2009). The psychometric properties of the older people's quality of life questionnaire, compared with the CASP-19 and the WHOQOL-OLD. Curr. Gerontol Geriatr Res. doi.org/10.1155/2009/298950.

4. Buford, T. W. (2016). Hypertension and aging. Ageing Res. Reviews, 26, 96-111. doi.org/10.1016/ j.arr.2016.01.007.

5. Culpepper, D., Killion, L. (2017). Effects of Exercise on Risk-Taking. Phys. Activity Rev, 5, 1-5. doi: http://dx.doi.org/10.16926/par.2017.05.01.

6. Division of Ageing and Seniors: Physical activity and older adults from Canada; 2011. Available at: http://www.phac-aspc.gc.ca/seniors-aines/indexeng. php. Accessed Aug 1, 2011.

7. Franceschi, C., Motta, L., Motta, M., et al. (2008). The extreme longevity: the state of the art in Italy. Experimental Gerontology, 43, 45-52. doi: http://dx.doi.org/10.16926/par.2017.05.0110,1016 / j.exger.2007.06.006

8. Hallal, P. C., Andersen, L. B., Bull, F. C., Guthold, R., Haskell, W., Ekelund, U. (2012). Global physical activity levels: surveillance progress, pitfalls, and prospects. Lancet. 2012, 380, 247-257. doi.org/10,1016 / S0140-6736 (12) 60646-1.

9. Chovanová, E. (2018). Differences in motor coordination levels between the Slovak and Portuguese school-aged populations. Phys. Activity Rev, 6, 251-256. doi.org/10.16926/par.2018.06.29.

10. Lee, I. M., Shiroma, E. J., Lobelo, F., Puska, P., Blair, S. N., Katzmarzk, P. T. (2012). Effect of physical inactivity on major non-communicable diseases worldwide: an analysis of burden of disease and life expectancy. Lancet, 380, 219-229. doi.org/10,1016 / S0140-6736 (12) 61031-9.

11. Newson, R. S., Kemps, E. B. (2007). Factors that promote and prevent exercise engagement in older adults. J. Aging Health, 19(3), 470-481. [PubMed: 17496245]. doi.org/10,1177 / 0898264307300169.

12. Urgacz, K., Cholewa, J., Uher, I., Sahin, B., Cholewa, J. (2018). Senior Fitness Test in assessing the effectiveness of physical rehabilitation in the context of Parkinson's disease patients' quality of life. Phys. Activity Rev, 6, 110-116. doi: http://dx.doi.org/10.16926/par.2018.06.15.

13. Troen, B. R. (2003). The biology of aging. Mt. Sinai J. Medicine, 70, 3-22.

14. Wen, C. P., Wai, J. P., Tsai, M. K., et al. (2011). Minimum amount of physical activity for reduced mortality and extended life expectancy: a prospective cohort study. Lancet, 378, 1244-1253. doi.org/10.1016/S01406736(11)60749-6.

Стаття надійшла до редакції 28.05.2019 р. 